Ilmo. Senhores

Bernardo Gontijo, Silvio Marques, Everton do Vale MD. Editores dos Anais Brasileiros de Dermatologia

\section{Senhores Editores,}

Ao cumprimentá-los cordialmente, refiro-me à excelente qualidade que os $A B D$ vêm alcançando. Particularmente referente ao volume 82 , n 5 , set/out 2007, que para quem trabalha com dermatologia infecciosa foi um presente, gostaria de tecer alguns comentários:

$\mathrm{O}$ editorial Informação de ponta $x$ enfoque prático. Qual o perfil ideal de um periódico médico? exprime, de forma absolutamente clara, o equilíbrio necessário entre a vida prática e a melhor evidência científica.

O manuscrito, Paracoccidioidomicose: freqüência, morfologia e patogênese de lesões tegumentares, de Marques SA, Cortez DA, Lastória JC, Camargo RMP e Marques MEA é completo e, a partir dos 152 casos estudados, nos permite visitar os diversos aspectos de um problema de saúde pública.

Em Hanseníase: uma doença genética? de Costa FP e Mira M, traz aos nosso pares, em linguagem acessível, as conquistas mais recentes da ciência aportadas por um jovem brasileiro que já tem três publicações no NATURE. O professor Marcelo Mira é, sem dúvida, um expoente que orgulha o país.

Finalmente, não posso me furtar a lamentar que o manuscrito Prevalência de dermatoses na rede básica de saúde de Campinas, São Paulo, Brasil, de Júnior AS, Andrade MGG, Zeferino AB, Alegre SM, Moraes AP e Velho PENF, seja publicado sem minimamente citar a referência Perfil nosológico das consultas dermatológicas no Brasil de autoria institucional da Sociedade Brasileira de Dermatologia. Ora, quando autores de um manuscrito escolhem um periódico para publicar, é imperativo que em sua revisão bibliográfica eles, pelo menos, verifiquem o que este mesmo periódico publicou sobre o assunto. Em não tendo feito, e os referees não atentando para tal fato, deixou a discussão do assunto pobre e comparada a artigos pontuais internacionais, sem o fazê-lo com uma amostra inquestionável e publicada pela nossa sociedade, que vem subsidiando a formulação de política pública em âmbito nacional. Lamentável.

Recebam, senhores editores, meu abraço e meu respeito.

Atenciosamente,

Gerson Penna 